Chapter 2

\title{
The Pioneers, Institutions, and Vehicles of Planning History
}

\author{
Stephen V. Ward
}

Since the 1970s, there has been a remarkable flowering of research and publications about the history of urban and regional planning. This growth has been apparent in most major world regions, though it has been most striking in the affluent countries with the most developed higher education and research infrastructure. These also tend to have the most elaborate and historically-rooted modern planning traditions. In general, planning history has come from individual researchers, small research teams or clusters based in a variety of academic disciplines, including planning, history, geography, architecture and history of art. Yet, although some work was directly supported by specific research grants, research in planning history has not generally been a high priority for major research funders.

An intriguing question therefore presents itself: what produced this flowering of research into planning history? In part certainly, it coincided with the rise of a more generally questioning attitude to planning and its results in many parts of the world. In a particularly structuralist moment in 1981, one of the main pioneers of planning history equated it with the economic deceleration of the 1970s after the long post-1945 boom, prompting a process of critical reflection and taking stock (Sutcliffe 1981b). Whatever its fundamental cause, this growth of planning history research has created a new sub-field of specialist knowledge within the academic disciplines of planning and closely related subjects. It also forms part of a longer term trend to diversification within the discipline of history. Over recent decades, historians have identified new subjects, less fixated on traditional concerns of nations, leaders, major events and economic achievements. More attention has been given to the everyday experience of the wider mass of people and factors (such as planning) which have 
shaped their lives. Alongside this, the volume of relevant archival material has grown spectacularly as new governmental and private records have become available and much material has been digitalized.

All these more general factors have undoubtedly been necessary for the historical turn in research into planning. Yet they are not alone sufficient to explain it. Clearly the intellectual curiosity of individual researchers has been fundamental but so too have a few key pioneering individuals who have been "intellectual entrepreneurs." Their seminal influence arose not just through their own work but more importantly in their realization that, if the new area of study was ever going to flourish, it needed dedicated networks, institutions and outlets. Only through these means could new and emergent works of planning history research by a wider group of researchers be nurtured and encouraged, benefit from informed criticism and advice and be published. The creation of this new and distinct intellectual space within which planning history has been able to grow has been of immense significance. It is something easily now taken for granted but, without which, it would have been difficult to establish the value of historical knowledge and analysis in the planning field. This chapter identifies and discusses the contribution of these pioneers together with the networks and the major vehicles of dissemination that they established.

\section{Gordon Cherry, Anthony Sutcliffe, and the History of Planning Group}

$<<$ Fig. 2.1 near here, caption: Tony Sutcliffe (L) and Gordon Cherry (R), the two founding fathers of the International Planning History Society and its predecessors, seen here at the joint conference of the Society of American City and Regional Planning History and the Planning History Group held in Richmond, Virginia in 1991 (courtesy of Gilbert Stelter). >>

The pioneers referred to in this chapter were certainly not the first to examine the history of planning. Historical writing about urban planning was evident even as the modern conception of planning began to crystallize in the early $20^{\text {th }}$ century. This body of literature 
continued to be refreshed with later studies, though less because of new scholarship than to reflect changing perspectives about the nature of planning through the century. Thus the emergence of more functionalist thinking in relation to the understanding of architecture and urban design by the 1930s and 1940s saw a rethinking of urban history and attempts to shape the city. By the 1950s and 1960s, however, some notable contributions to historical scholarship about planning were appearing in several countries (Ward, Freestone, and Silver 2011). Yet it was not until the 1970s that specifically planning history networks began to give a robust foundation for these studies, allowing them to be refined and synthesized.

The key figures who laid this foundation were two English university academics. One, Gordon Cherry, had come from a geography background, before working as a practicing town planner (Boulton 1996). Alongside his day-to-day work, he developed an interest in the social and historical roots of contemporary planning. In 1968 he became deputy director of the new Centre for Urban and Regional Studies at the University of Birmingham. Two years earlier, in the History department of the same university, a young urban historian, Anthony Sutcliffe, was also appointed (Ward, Meller, and Rudkin 2012). He was to be the other key figure. Funded by the City of Birmingham, Sutcliffe, working with Roger Smith, was to research and write the third volume of the prestigious History of Birmingham (Sutcliffe and Smith 1972).

By 1970, therefore, Cherry and Sutcliffe had discovered each other's existence but had had little contact because neither was yet aware of the other's interest in planning history (Sutcliffe 1996). This was scarcely surprising since, until then, neither's work had matured sufficiently for them to have published anything of substance on the topic. In that year Sutcliffe published the fruits of his doctoral research on town planning in central Paris undertaken at the Sorbonne in Paris in a critically acclaimed book (Sutcliffe 1970). Cherry also published what was essentially a historical examination of the social roots of town 
planning, a book which laid down a marker for the importance of history in the academic discipline of planning (Cherry 1970). Within the next few years, both published other books about planning history (Sutcliffe and Smith 1972; Sutcliffe (ed.) 1974; Cherry 1972, 1974, 1975). Now both realized that, from their different starting points, they had an interest in common.

During 1973-4 Sutcliffe (by then at the University of Sheffield) and Cherry began to hatch plans for a study group focused on planning history. Its template was the Urban History Group, founded by the pioneering British urban historian H. J. (Jim) Dyos in 1963 (Cannadine 1982), an offshoot of the Economic History Society. But the new study group was entirely independent. The first meeting of what was soon being called the History of Planning Group occurred at the Centre for Urban and Regional Studies, Birmingham in October 1974. From their different disciplinary backgrounds, Sutcliffe and Cherry brought together around 30 interested people, a diverse group comprising academics with a few retired or practicing practitioners (Cherry 1984).

Other meetings soon followed, with British attendees and occasionally visitors from elsewhere. By the later 1970s, the multi-lingual Sutcliffe was, through his own research interests, developing active connections with France, Germany, North America and elsewhere. He knew that more researchers in other countries were becoming similarly interested in planning history. From the outset, Sutcliffe was eager to ensure that the History of Planning Group did not become locked into a solely British frame of reference.

\section{The First International Planning History Conference and the Planning History}

\section{Group}

Cherry, who soon became leader of the Group, also began to realize the value of making the network more completely international, a shift definitively signaled by the first 
international planning history conference, held in London in 1977. Organized largely by Sutcliffe, it brought together pioneers of planning history research and study from sixteen countries. The delegate list indicates almost 150 attendees (ICHURP 1977). Half came from Britain; significant groups came from the United States and West Germany; smaller numbers came from other European countries (including Poland and Czechoslovakia, then Communist states), as well as Canada, Japan, Australia and Lebanon (although its single delegate was actually a British national). Several were already well known figures and many subsequently became key figures in the international network of planning history.

Sutcliffe had also wanted to use the conference to cement links between planning history and urban history. But, although this link began promisingly, Jim Dyos died suddenly in 1978 and the Urban History Group lost its leader. While other urban historians did much to develop his legacy, no-one could immediately take his place (Cannadine 1982; Rodgers 1989). In time Sutcliffe might perhaps himself have assumed that role but he was by now largely and successfully engaged in planning history, most notably with a seminal study of the international bases of modern planning, Towards the Planned City (Sutcliffe 1981a). He certainly never abandoned urban history (Fraser and Sutcliffe (eds) 1983). By the early 1980s, however, he had real doubts whether the city, as distinct from the social, economic and political processes occurring within the city, was itself a valid subject for historical inquiry (Mandelbaum 1983).

Towards the end of the decade, the History of Planning Group was more snappily retitled as the Planning History Group (PHG) and formally organized on a membership basis, with Cherry continuing as Chairman. Occasional newsletters had originally been issued but in 1979, this method of Group communication was replaced by a more regular publication, Planning History Bulletin (PHB). In its second issue the Chairman reported 243 members, of whom 141 were based in the UK and 102 from other countries. Of these, 41 were based in the 
United States, 13 in Canada, 11 West Germany, 9 Italy, 5 Japan, 7 Netherlands, 4 Australia, 3 each from Poland and Sweden, 2 each from Spain and Switzerland and 1 each from France and New Zealand (Cherry, 1979). Thereafter growth was slower with 277 members in 1983, by then almost equally balanced between UK and non-UK (Cherry 1983). The late1970s/early 1980s growth in PHG's international membership emphasizes how much this UK-based society was reaching out to kindred spirits elsewhere.

Many PHG members were also, of course, members of other study groups and networks, typically reflecting their academic disciplinary affiliation. To some extent, such networks were also providing some outlet for the growing interest in planning history, yet in a less-focused way than was possible within PHG. Yet there is no evidence that any organized groups or networks that existed anywhere prior to the PHG were exclusively devoted to planning history. The years that followed the 1977 London conference saw the creation of planning history networks or clusters of varying degrees of formality based outside Britain, particularly during the 1980s.

\section{The origins of the Society for American City and Regional Planning History}

The largest cluster of kindred spirits, as can be seen, came from the USA and Canada, largely at that time associated with the American Urban History Group. This had been founded in 1954, an inspiration for Jim Dyos in Britain in the 1960s (Mohl 1998). By the 1970s, American urban history was a strongly established field, its leading figures already becoming well known to Sutcliffe (and he to them). The synergies between urban and planning history were perhaps stronger in North America than in Britain, as the conscious creation and shaping of towns and cities was more integral to the making of the USA as an urban nation than in Britain. Proportionately more American urban historians also examined 
the $20^{\text {th }}$ century, in contrast to their UK equivalents, who tended to focus on the Victorian and earlier periods, before the emergence of modern urban planning.

Even so, some American planning academics clearly felt this rising interest in planning history was not being fully acknowledged either within the urban history field or the city planning profession. Some, a minority, of the American attendees at the 1977 London conference were from planning rather than history schools, most notably John Reps, Donald Krueckeberg and Eugenie Birch. However, the direct influence of that Conference and the UK-based PHG on subsequent developments in the USA can be debated. At the very least, PHG was an important example that encouraged growing American interest in planning history. In 1981 Birch informed PHG of recent American planning history meetings held under the auspices of the main national organizations of historians, architectural historians and professional planners (Cherry 1981). Yet there was clearly some American reluctance to identify too closely with the UK-based body. Thus in April 1983 the Planning History Group, identified as an informal group of the Organization of American Historians, sponsored a lunch during that Organization's Cincinnati conference (Gerckens 1983). The informal group (about 30 attended the lunch) included urban historians (notably Blaine Brownell) and planners (notably Donald Krueckeberg). Greetings were read from Sutcliffe on behalf of the UK-based International Planning History Group, and the formalization of links with this organization was discussed but rejected. It was decided to continue informal arrangements, with Krueckeberg acting as link between the two Groups. On this basis, other early American planning history meetings continued, for example at the Association of Collegiate Schools of Planning conference in San Francisco in October 1983 (Krueckeberg 1984).

It is unclear whether any larger ambition lay behind the decision to avoid a closer relationship with the Cherry/Sutcliffe network. What is definite is that in 1986 a new and completely independent American study organization specifically devoted to planning history 
was formed, the Society for American City and Regional Planning History (SACRPH) (http://www.sacrph.org/). Citing the opening speeches at a SACRPH conference a few years later, the American urban historian, Carl Abbott, attributed its formation to essentially national and professional frustrations. Its creators were "city planning school faculty and practitioners who were tired of seeing the history of the planning profession given the polite brushoff in academic curricula and professional conferences" (Abbott 1992). Certainly its driving force, Larry Gerckens, although present at the 1983 lunch and author of the brief report in the Planning History Bulletin, had, as yet, had no direct contacts with the CherrySutcliffe network.

Gerckens, a man of astonishing energy and enthusiasm, was professor of planning at Ohio State University though had retired to set up as a freelance teacher and planning consultant. His pioneering contribution to planning history was to raise its professional profile through teaching, educational administration, and professional practice, rather than research authorship. He hosted the first two conferences of SACRPH, both in Columbus, Ohio (in 1986 and 1987), which attracted 30 and 50 delegates respectively; by the third event, in Cincinnati in 1989, the number had grown to 100.

American urban historians did not themselves in 1986 have a network organization, which might have responded more effectively to this historical yearning felt by planning academics and practitioners. (The Urban History Group created by the first generation of American urban historians had become moribund by the mid-1970s (Mohl 1998).) Now change was afoot, and a new Urban History Association (UHA) was formed in 1988 that was soon enthusiastically supported by younger American urban historians (Wade 1989). A key aim for the new organization was to foster meaningful connections between urban historians and other disciplines. Thus the two quite new organizations for American planning and urban 
history quickly established close and friendly relations, their memberships and leaderships soon overlapping.

The UHA lent its support to SACRPH's fourth conference at Richmond, Virginia, in 1991, which attracted some 250 delegates, making it the largest planning history gathering which had then occurred anywhere (Abbott 1992). Organized by Chris Silver, then of Virginia Commonwealth University, this event was also a landmark in another respect: it involved the PHG, becoming its fifth international conference. The number of international attendees was not large but they were diverse in origin and included key figures from planning history in several different countries. It was also almost certainly the first time that Gerckens, Cherry, and Sutcliffe had actually met.

\section{The development of planning history networks in West Germany}

Meanwhile individual leaders had emerged in other countries, and clusters or network groupings had formed around them. The most developed was in West Germany (as it still was). Here there was a strong and growing interest in the history of urban planning, coming, as elsewhere, mainly from urban history and planning and related disciplines, including architectural history. Two important journals Informationen zur modernen Stadtgeschichte (founded in 1970) and Die Alte Stadt (1974) published research on urban planning and development, urban history and historic conservation. It was therefore quite natural that these concerns soon impinged on the history of planning itself. In part this was simply recognising Germany's seminal role in the emergence of modern urban planning. Yet this was scarcely celebrating past successes, which was certainly a contributory aspect in the UK and USA. More than anywhere else, the growth of planning history in West Germany from the 1970s became an integral part of a wider critical reflection on planning, a way to draw lessons. 
Thus the country's planning historians did not (possibly could not) shy away from "the dark side" of Germany's history and how planning, though ostensibly a technical, apolitical field, was also a real part of this. For example, the opening keynote address of the 1977 international conference by Gerd Albers, from the Technical University of Munich, was about German planning through a turbulent century that saw major regime changes (Albers 1980). Albers was already something of an elder statesman of German planning, who played an important role in encouraging the study of its history, especially of the discipline of planning and its key figures. Soon, however, younger heads were also hard at work and particular clusters of planning history discourse soon began to emerge.

The most energetic and productive was associated with the Lehrstuhl für Planungstheorie und Stadtentwicklung at the Technische Hochschule inAachen, headed by Gerhard Fehl. Fehl and his close colleague, Juan Rodriguez-Lores both attended the 1977 London conference. From 1981, with Werner-Reimers Foundation funding, they organized biennial planning history colloquia in the attractive small-town setting of Bad Homburg (PHB 1986a). Invited German and international experts from various disciplines participated, fostering rigorous debate. The group took a wide view of planning history, embracing how the urban environment was produced (PHB 1981; Weiland 1983). Fehl also played an important role encouraging younger German talents, including Harald Bodenschatz, Karl Friedhelm Fischer and Dirk Schubert, laying the basis for a new generation of planning historians. The results of the colloquia were published in a series of edited works (eg Fehl and Rodriguez-Lores (eds) 1983; Rodriguez-Lores and Fehl (eds) 1985; 1988; Harlander and Fehl (eds) 1986; Bollerey, Fehl, and Hartmann (eds) 1990).

Other individuals were soon researching and writing planning history elsewhere in West Germany (particularly in the nearby Dortmund). Some German architectural historians, notably Harmut Frank, Niels Gutschow and Werner Durth, were also becoming increasingly 
interested in the history of urban planning. But it was the planning academics at Aachen who formed the main early West German hub for planning history endeavour.

\section{Planning history networks in other countries}

A significant hub of activity that grew principally from a disciplinary focus on architectural history was at the Istituto Universitario di Architettura di Venezia (Venice) in Italy. Here were several significant pioneers of modern urban planning history, including Giorgio Piccinato (author of a key work on early German planning history and contributor to the Aachen group's colloquia) and Donatella Calabi, both of whom attended the 1977 London conference.

Another important grouping, also focused on architectural history, grew in the Netherlands around Ed Taverne at the Instituut voor Kunstgeschiedenis (art history institute) at the University of Groningen during the later 1970s/early 1980s (Taverne 1985). From here came a string of important research studies as new talents were nurtured, notably Koos Bosma, Cor Wagenaar, and Gerrie Andela. Taverne also headed an informal Dutch association for the history of spatial planning, created in the early 1980s. The association also brought in other Dutch innovators in planning history, including Peter de Ruijter (whose premature death in 1986 removed an important pioneering talent) and Arnold van der Valk from the Instituut voor Planologie, University of Amsterdam (Faludi and van der Valk 1994, ix). In the longer term, however, the architectural historians have remained the most active Dutch researchers in this field.

In other countries, national and regional standard bearers included Shun-ichi Watanabe, then of the Building Research Institute of the Japanese Ministry of Construction. Watanabe's fluency in English and familiarity with the British and American planning scenes made him a vital intermediary. From 1977 when he attended the London conference, he 
quickly developed warm personal links with both Cherry and Sutcliffe. Showing the same extraordinary energy and commitment that characterized many of the pioneers, he took many important initiatives in succeeding years to establish an intellectual and professional space for planning history in Japan.

Thus in 1978 he organized a pioneering session devoted to planning history at the annual conference of the City Planning Institute of Japan. Out of this came a Japanese Planning History Group that held annual meetings (Watanabe 1985) through which Watanabe recruited a sizeable Japanese contingent of the UK-based Planning History Group (33 members by 1986). From 1980, he also led the Housing Policy Research Group in Japan (actually a planning history group but so-called to secure funding). This existed until 1988 when Watanabe moved to a post less focused on planning history and funding lapsed. It was fitting testimony to his efforts that the third International Planning History Conference, the first one outside Britain, was held in Tokyo (in 1988).

<<Fig. 2.2 near here, caption: From 1977, international conferences were the key discursive and networking events of planning history. $•$ The 1988 event was the first one outside Britain, held jointly with the City Planning Institute of Japan. • The 1996 gathering at Thessaloniki in Greece was the second conference held under the auspices of the International Planning History Society. $\bullet$ The 1998 Sydney Conference marked a step change in the scale of the IPHS conferences with over 300 delegates. • The 2006 Conference in New Delhi was the first major IPHS event to be held in a developing country • The 2010 Conference in Istanbul took place at the node of several civilizations• The 2016 IPHS conference in Delft brought together more than 400 participants and resulted in a series of four proceedings. >>

Similarly, other pioneers emerged elsewhere. In Australia, influenced by American and British developments, urban history was growing into a very significant field of research interest. By the 1970s, this was extending into planning history and the creation of the 
British-based Planning History Group was an important stimulus. In 1986 the first definite steps to create a loose Australian Planning History Group were taken by Alan Hutchings of the South Australian Planning Commission (PHB 1986b). More than elsewhere, much initial impetus came from practitioners and the first national meeting occurred within the Royal Australian Planning Institute Congress (celebrating the Australia's bicentennial) in Melbourne in September 1988 (Hutchings 1988). To coincide, Hutchings and Robert Freestone edited a special planning history issue of the Institute's journal Australian Planner (Freestone and Hutchings 1988).

Freestone soon emerged as Australia's leading planning historian, especially after returning to academic life at the University of New South Wales in 1991. Like his equivalents elsewhere, however, he was more than an individual researcher. With Hutchings and others, he ensured that local interests in planning history became part of a national network, also embracing New Zealand. Without ever becoming a formal membership-based organization, the Australasian Urban History / Planning History Group (as it is now called) has become a network with regular biennial conferences and an active website (AUHPHG 2015).

Individuals and networks were also active in other countries, showing varying degrees of connection to the Cherry/Sutcliffe network. Some national networks have been stimulated by organizing international planning history conferences, notably in Greece and Finland during the 1990s (PH, 1993; PH 1999). Yet neither were simple clones of the PHG model.

Moreover, there were also some countries with quite different networks than those of the Anglophone pattern.

\section{Publishing planning history}

The original UK networking model, meanwhile, continued to develop, creating important outlets to disseminate planning history studies. In fact, the most important and 
enduring direct outcome of the early conferences was a book series launched by Cherry and Sutcliffe, again taking a central role in defining the new field (Ward, Meller, and Rudkin 2012). The first books captured permanent value out of the transitory sense of intellectual excitement and cohesion that the first conferences uncovered. Published initially by Mansell, later by Spon and finally Routledge, the initial emphasis on conference-derived collections, gave way to more authored works or themed edited collections. The series soon established itself, with the major conferences, as the premier vehicles for promoting and disseminating planning history. To date, over fifty books have appeared in the series. They set high standards of scholarship for the sub-field of planning history and charted new dimensions of planning history research. All remain essential reading on their respective subjects.

<<Fig. 2.3 near here, caption: Ann Rudkin, planning history publisher extraordinaire, has edited every single book in the planning history series established by Cherry and Sutcliffe. She is seen here in 1980 at Bekonscot model village in Beaconsfield, England, with Peter Hall, perhaps the best known planning historian of all. The picture shows them as the giants of their respective crafts that they truly are (courtesy of Ann Rudkin). >>

Cherry and Sutcliffe were assisted by a remarkable publishing editor, Ann Rudkin (Fig. 2.2) (originally Ann Drybrough-Smith, under which name she edited the early volumes). It was her editorial skills and frequent battles against default tendencies to blandness and mean spiritedness within large academic publishers that ensured planning history became equated with attractive, high quality books with long shelf lives. She ensured that they really did look more interesting and authoritative than typical books on planning. Uniquely, her editorial skills were combined with an extraordinary knowledge of planning and planners. She deserves recognition as a pioneer of planning history in her own right.

After the conferences and the book series, the third major vehicle on which planning history moved forward was (and remains) the academic journal, Planning Perspectives, defined as an "international journal of history, planning and the environment." It was not, 
however the first planning history journal, a distinction held by Planning History Bulletin. Over time PHB grew from a newsletter into a magazine, renamed Planning History in 1988. Yet, although it published research-based shorter pieces, there was no outlet for longer, refereed papers until Planning Perspectives appeared in 1986. Unlike the PHB/Planning History, which was produced and distributed by the PHG, the new refereed journal came from the stable of a major publisher, originally under the Spon imprint, later Routledge.

Initially appearing three times a year, then quarterly, Planning Perspectives was a continuing outlet for high quality international planning history research and scholarship. In itself it played a key role in defining an intellectual space for planning history. It was never the only outlet for planning history scholarship, with planning journals such as Die Alte Stadt, Town Planning Review, and Journal of the American Association of Planners having honorable records in this respect. However Planning Perspectives was for many years the only one exclusively dedicated to that field. Here the combination of historical approach and focus on planning was automatically understood as academically valid; it was not judged on a case-by-case basis as planning historians submitting to many other journals found. Yet, by appearing so consistently and now into its fourth decade, it has helped validate planning history in the minds of other editors and readers.

Cherry and Sutcliffe were founding editors and co-edited the journal until Cherry's death in 1996, after which Sutcliffe edited it alone until 2001. Successive editors have been able to build on this firm grounding, especially in conjunction with IPHS international conferences. Its global reach and the consistently high quality have ensured that it has become a valued part of the Routledge journals list. Now through electronic publication it has become very widely available to academic and other major libraries throughout much of the world. In 2001, it was joined by the American Journal of Planning History, associated with SACRPH but also increasingly international in its outlook. After some initial rivalry, the two 
journals co-exist productively, proving the quantity and quality of planning history scholarship that now exists. In 2008, Planning History became a special IPHS section within Planning Perspectives.

\section{Later developments}

The 1990s saw several changes in the institutional bases of planning history and cognate areas. Most directly relevant was that the PHG became the International Planning History Society (IPHS) in 1993. This came to a head because the development of SACRPH as a large nationally-based body created an anomalous situation for its members. Many wished to participate in PHG as an international organization but not as a UK national body. However there had been some dwindling of interest during the 1980s in a purely UK-based organization. Both Sutcliffe and Cherry were already thinking that internationalization represented the most sensible direction. They (especially Sutcliffe) also feared that if the PHG did not take the initiative, SACRPH eventually would. After discussions at the 1991 Richmond conference and consultation of PHG membership the PHG was recast as the IPHS. Over time, this change has had important consequences. Cherry, having remained Chairman of the PHG for its whole existence, became first President of IPHS and was succeeded on his death by another UK President, the present author. Gradually though IPHS began to lose many signs of its original national identity. The following Presidents have been Australian (Robert Freestone), Finnish (Laura Kolbe), American (Eugenie Birch) and German (Dirk Schubert) with an Australian (Christine Garnaut) set to succeed.

The same trend has been apparent in IPHS's most important achievement, continuing what Sutcliffe and Cherry began in 1977. Since 1994 there has been a regular program of biennial conferences which have moved planning history into new regions of the world, generating new interests. Successively these events were held in Hong Kong (1994), 
Thessaloniki (1996), Sydney (1998), Helsinki (2000), London/Letchworth (2002), Barcelona (2004), New Delhi (2006), Chicago (2008), Istanbul (2010), Sao Paulo (2012), Saint Augustine, Florida (2014), Delft (2016) and Yokohama (2018).

Meanwhile, there has been some formalization of national planning history or related networks in other countries. The internet has made it easier to create a network organization compared to the 1970s. Now a well-designed and regularly updated website can, with continued development and updating, credibly (and creditably) present and link a community of scholars, especially if reinforced by newer electronic social media, an aspect rich with opportunities for fresh initiatives. Organizationally, the most significant shifts since the 1990s have been within urban history, where a European Urban History Association was reconstituted as an active network in 1992. This body which developed an active program of conferences and meetings, encouraging stronger network membership organizations to develop at national level, notably the French Société Française d'Histoire Urbaine, formed 1998 (http://sfhu.hypotheses.org/) and Germany, the Gesellschaft für Stadtgeschichte und Urbanisierungsforschung (GSU), formed 2000 (www.gsu.tu-darmstadt.de/). These various organizations, and those elsewhere, have to some extent involved themselves in planning history, especially so in Germany where the GSU has a very active planning history membership and program.

More recently there have also been promising new initiatives in Japan in 2010 where a Planning Heritage Study Group focusing on planning historical themes was established with funding from the Japan Society for the Promotion of Science (JSPS). Its first seminar was held in 2013. Meanwhile in China in 2012, an Academic Committee of Planning History and Theory was established, chaired by Dong Wei of the Department of Planning, Nanjing University. Organized under the auspices of the City Planning Institute of China, the new body held its first symposium meeting in May 2013 (PP 2013). In November of that year the 
new Japanese group and members of the Chinese body held a two-day joint workshop in Tokyo during the City Planning Institute of Japan's annual conference, exploring future academic collaboration (Nakajima 2015).

\section{Conclusion}

The story is then a continuing and unfinished one. Most pioneers of the first generation have now departed the scene and others are appearing, while the institutions remain, though are not unchanging. It is probably inevitable and desirable that some process of institutional making and remaking continues, as new pioneers with ideas, energy and organizational skills appear. The original duality of planning history within, alongside, or sometimes in opposition to urban and architectural history remains. The greatest continuity, however, has been in relation to the vehicles of planning history, where conferences and publications continue to be the most tangible products of this field. This chapter must end by honoring those who initiated all these things. Without them, the planning history field would not exist.

\section{Related Topics}

Freestone: Writing planning history in the English-speaking world

Monclús, Díez: Urbanisme, Urbanismo, Urbanistica

Orillard: Urbanisme and the Francophone Sphere

Kress: The German Traditions of Städtebau and Stadtlandschaft

Hein: Translating the Idioms of Japanese Planning

\section{References}

Abbott, C. (1992) Richmond Conference, Urban History Newsletter, March, No. 7, 1-2. 
Albers, G. (1980) Town Planning in Germany: Change and Continuity under Conditions of Political Turbulence, in Cherry (ed.), 145-160.

AUHPHG (Australasian Urban History / Planning History Group) 〈http://uhphg.com>

Bollerey, F., Fehl, G. and Hartmann, K. (eds) (1990) Im grünen wohnen - im blauen plannen: eine lesebuch zur gartenstadt, Hamburg: Christians.

Boulton, J. (1996) Obituary: Professor Gordon Cherry, The Independent, $2^{\text {nd }}$ March. http://www.independent.co.uk/news/people/obituary-professor-gordon-cherry$\underline{1339852 . h t m l}$

Cannadine, D. (1982) Urban History in the United Kingdom: the 'Dyos Phenomenon' and after, in Cannadine, D. and Reeder, D. (eds) Exploring the Urban Past: Essays in Urban History by H. J. Dyos, Cambridge: Cambridge University Press, 203-21.

Cherry, G. E. (1970) Town Planning in its Social Context, London: Leonard Hill.

Cherry, G. E. (1972) Urban Change and Planning: A History of Urban Development in Britain since 1750, Henley: Foulis.

Cherry, G. E. (1974) The Evolution of British Town Planning, Leighton Buzzard: Leonard Hill.

Cherry, G. E. (1975) Environmental Planning 1939-1969, Vol. II, National Parks and Recreation in the Countryside, London: HMSO.

Cherry, G. E. (1979) Chairman's Note, Planning History Bulletin, Vol 1, No. 2, unpaginated front matter.

Cherry, G. E. (ed.) (1980) Shaping an Urban World, London: Mansell.

Cherry, G. E. (1981) Chairman's Note, Planning History Bulletin, Vol. 3, No. 2, 1-2.

Cherry, G. E. (1983) Chairman's Note, Planning History Bulletin, Vol. 5, No. 1, unpaginated front matter. 
Cherry, G. E. (1984) Ten Years of the Planning History Group, Planning History Bulletin, Vol 6, No. 2, unpaginated front matter.

Faludi, A. and van der Valk, A. (1994) Rule and Order: Dutch planning doctrine in the twentieth century, Dordrecht: Kluwer.

Fehl, G. and Rodriguez-Lores, J. (eds) (1983) Stadterweiterungen1800-1875, Hamburg: Christians.

Fraser, D. and Sutcliffe, A. (eds) (1983) The Pursuit of Urban History, London: Arnold.

Freestone, R. and Hutchings, A. (eds) (1988) The Australian Planner (1988) Planning History Special Issue, Vol 26, no 3.

Gerckens, L. C. (1983) The 'U. S.' Planning History Group, Planning History Bulletin, Vol. 5, No. 2, 17.

Gesellschaft für Stadtgeschichte und Urbanisierungsforschung, < http://www.gsu.tu$\underline{\text { darmstadt.de/> }}$

Harlander, T. and Fehl, G. (eds) (1986) Hitlers Sozialer Wohnungsbau, Hamburg: Christians. Hutchings, A. (1988) Australian Planning History Group, Planning History. Vol. 11, No. 1, 32.

ICHURP (International Conference on the History of Urban and Regional Planning), (1977) Conference List (typescript document).

Kreuckeberg, D. (1984) Association of Collegiate Schools of Planning, Planning History Bulletin, Vol. 6, No. 1, 3-4.

Lees, L. H. (1993) European Association of Urban Historians, Urban History Newsletter, March, No. 9, 1-4.

Mandelbaum, S. J. (1985) H. J. Dyos and British Urban History, Economic History Review, New Series, Vol. 38, No. 3, 437-447. 
Mohl, R. (1998) Urban History, in Woolf, D. R. (ed) A Global Encyclopedia of Historical Writing, Vol 2, New York: Garland, 907-13.

Nakajima, N. (2015) Chinese planning history and Japanese planning history: exploring the possibility for future academic co-operation - a workshop in the annual conference of the City Planning Institute of Japan, Tokyo, 8-9 November 2013 Conference report, Planning Perspectives, Vol. 30, No. 2, 291-6.

PH (1993) Hellenic Planning and Urban History Association, Planning History, Vol. 15, No.

\section{3,5 .}

PH (1999) Finnish Society of Urban History, Planning History, Vol. 21, No. 3, 3.

PHB (1982) The Origins of Town Planning in Germany, 1850-1875, Vol. 4, No. 1, 5-8

PHB (1986a) West Germany’s “Study Group for Planning History,” Planning History

Bulletin, Vol. 8, No. 1, 4-5.

PHB (1986b) Australian Planning History Group, Planning History Bulletin, Vol. 8, No. 3, 8.

PP (2013) Announcement: Formation of the Academic Committee of Planning History and Theory, China, Planning Perspectives, Vol. 28, No. 4, 643.

Rodger, R. (1989) The Dyos Legacy: Leicester University and Urban History, 1978-88, Urban History Newsletter, March, No. 1, 1.

Rodriguez-Lores, J. and Fehl, G. (eds) (1985 and 1988) Städtebaureform 1865 - 1900, (2 Volumes), Hamburg: Christians. Société Française d'Histoire Urbaine <http://sfhu.hypotheses.org/>

Society for American City and Regional Planning History, <http://www.sacrph.org/> Sutcliffe, A. (1970) The Autumn of Central Paris: The defeat of town planning, 1850-1970, London: Edward Arnold.

Sutcliffe, A. and Smith, R. (1972) Birmingham 1939-1970, Oxford: Oxford University Press. 
Sutcliffe, A. (ed.) (1974b) Multi-Storey Living: The British Working Class Experience, Beckenham: Croom Helm.

Sutcliffe, A. (1981a) Towards the Planned City: Germany, Britain, the United States and France 1780-1914, Oxford: Basil Blackwell.

Sutcliffe, A. (1981b) Why Planning History, Built Environment, Vol 7, No. 2, 65-7.

Sutcliffe, A. (ed.) (1984) Metropolis 1890-1940, London: Mansell.

Sutcliffe, A. (1996) A Planning Perspective, Planning History, Vol 18, No. 1, 7-8.

Taverne, E. R. M. (1985) Content and Containers: New Approaches to Architectural, Urban and Planning History in the Netherlands, Planning History Bulletin, Vol. 7, No. 1, 49-58.

Wade, R. C. (1989) From the President, Urban History Newsletter, March, No. 1, 2.

Ward, S. V., Freestone, R. and Silver, C. (2011) The 'new' planning history: reflections, issues and directions, Town Planning Review, Vol 82, No. 3, 231-61.

Ward, S. V., Meller, H. and Rudkin, A. (2012) A tribute to Anthony Sutcliffe 1942-2011, Founding joint editor with Gordon Cherry 1986-1996, Editor 1986-2001, Planning Perspectives, Vol. 27, No. 2, April, 167-71.

Watanabe, S. J. (1985) Japan: A growing interest in the historical and international dimensions, Planning History Bulletin, Vol. 7, No. 2, 1985, 15-7.

Weiland, A. (1983) The Beginning of Modern Town Planning: the Bad Homburg Symposium, Planning History Bulletin, Vol. 5, No. 3, 1-3. 